\title{
SERVICE QUALITY, BRAND LOYALTY, AND PROFIT GROWTH IN UK BUDGET HOTELS
}

\author{
YUKSEL EKINCI,* DIA ZEGLAT, $\dagger$ and GEORGINA WHYATT $\ddagger$ \\ *Business School, Oxford Brookes University, Wheatley Campus, Wheatley, Oxford, UK \\ $\dagger$ Faculty of Management and Law, University of Surrey, Guildford, UK \\ \$Marketing and Operations Management, Business School, Oxford Brookes University, \\ Wheatley Campus, Wheatley, Oxford, UK
}

\begin{abstract}
Although past studies advocate a positive impact of service quality on business performance, empirical studies investigating the nature of the relationship between service quality and profit growth in the hotel industry are limited. This study contributes to an ongoing debate as to whether service quality has a direct or indirect influence on profitability in the hotel industry. The data were collected from a national budget hotel company in the UK and the research hypotheses were tested through structural equation modeling via the LISREL software. The findings of the study found that service quality had a positive influence on brand loyalty and premium price. The effect of service quality on profit growth was indirect and mediated by premium price, brand loyalty, and sales growth.
\end{abstract}

Key words: Service quality; Profit growth; Brand loyalty; Budget hotels

\section{Introduction}

During the past three decades, academics have spent significant time and effort trying to understand perceived quality and its impact on business performance (Zeithaml, Berry, \& Parasuraman, 1996). A growing number of studies suggest that quality goods and services will result in higher profitability and business growth (e.g., Duncan \& Elliott, 2002; Garuana \& Pit, 1997; Hardie, 1998; Hasan \& Kerr, 2003; Kimes, 2001; Raju \& Lonial, 2002; Zhang, 2000). However, as suggested by Babakus, Bienstock, and Scotter (2004) “despite nearly two decades of research on quality improvements efforts, the relationships between customer perceptions of quality and financial outcomes are still being debated" (p. 174). Zeithaml (2000) argues that the link between service quality and organizational profitability is indirect and mediated by various complex variables such as consumer satisfaction, consumer retention, perceived value, operations costs, revenues, and market share. An alternative school of thought claims that the relationship between quality and profitability is either weak or negative because when offering high quality, production costs may be increased and 
will therefore have an adverse effect on the firm's profitability (Adam, 1994; Harrington \& Akehurst, 1996).

To the best of our knowledge an investigation of the relationship between perceived service quality and profit growth has not been undertaken in the budget hotel sector. This sector is one of the fastest growing in the UK. Following research undertaken in 2007, industry consultants envisage the budget hotel sector growing by some $10 \%$ to 2012 and approximately 5\% in the subsequent 5 years and $2.5 \%$ in the decade after that (Gold, 2008; Kuhn, 2007). Increasingly price conscious, and knowledgeable, customers are creating new challenges for service providers in the budget hotel sector. Given the growing number of budget hotel brands (e.g., Ibis, Holiday Inn Express, Formula 1, Travelodge) and the increasing competition for sites in the UK, quality of service is considered to be key to building competitive advantage and business growth (Johnson, 2003). Intense competition and high indirect costs in the budget hotel industry create a challenging price/cost environment in which it is vital to understand the mediators between service quality and profit growth.

The examination of the relationship between service quality and profit growth in the budget hotel sector contributes to the ongoing debate as to whether service quality has a direct or indirect impact on business performance. This study responds to the call for further research by prominent scholars. For example, Zeithaml (2000) argues that research on the direct relationship between service quality and profits has shown both positive effects in a limited number of studies and no effects in other studies. Hardie (1998) comments that although the positive effect of service quality on firms' profitability is theoretically compelling, empirical studies are lacking to validate this theory. Despite the enormous quantity of literature in the area of services marketing, there is a notable lack of empirical research on service quality in the areas where price sensitivity is significant, such as budget hotels.

This study develops a model from the established literature and gathers data from a nationwide hotel chain, in order to investigate the relationships between service quality and profit growth in the UK budget hotel sector. Hence, the aim of this study is to respond to the following research questions: What is the relationship between service quality and profit growth? Is the relationship between service quality and profit growth direct or indirect in the budget hotel sector?

\section{The Research Model}

Despite a history of investigation into the relationship between service quality and profitability, its exact nature is still being debated. Some of the past studies advocate that service quality has a direct effect on a range of business performance indicators such as sales volume and return on capital employed (ROCE) (e.g., Duncan \& Elliott, 2002: Garuana \& Pit, 1997; Hasan \& Kerr, 2003; Hendricks \& Singhal, 1997; Philips, Change, \& Buzzell, 1983; Raju \& Lonial, 2002; Zhang, 2000). Other studies suggest that the direct influence of service quality on profitability is weak and can be negative in some situations because offering high quality product and services increases the cost of production (Adam, 1994; Harrington \& Akehurst, 1996; Sterman, Repenning, \& Kofman, 1997). Given this debate we have focused on unpacking the relationship between service quality and profit growth and developed a research model as shown in Figure 1.

As can be seen from Figure 1, the research model proposes that a firm that offers better service quality $(\mathrm{H} 1)$ is able to charge premium price (Raju \& Lonial, 2002; Rust, Lemon, \& Narayands, 2004; Rust, Moorman, \& Dickson, 2002; Rust, Zahorik, \& Keiningham, 1995). In turn, premium price will have a positive influence on sales growth and profit growth (H5 and H6). The path from service quality to brand loyalty suggests that service quality $(\mathrm{H} 2)$ will be likely to have a positive influence on brand loyalty (e.g., Wilkins, Merrilees, \& Herington, 2010). Furthermore, brand loyalty will be likely to have a positive impact on sales growth (H7). Similarly sales growth will have a positive influence on profit growth (H8). Finally, our study investigates whether the effect of service quality on sales growth (H3) as well as profit growth (H4) is direct or mediated by brand loyalty and premium price (Hardie, 1998; Rust et al., 2002). 


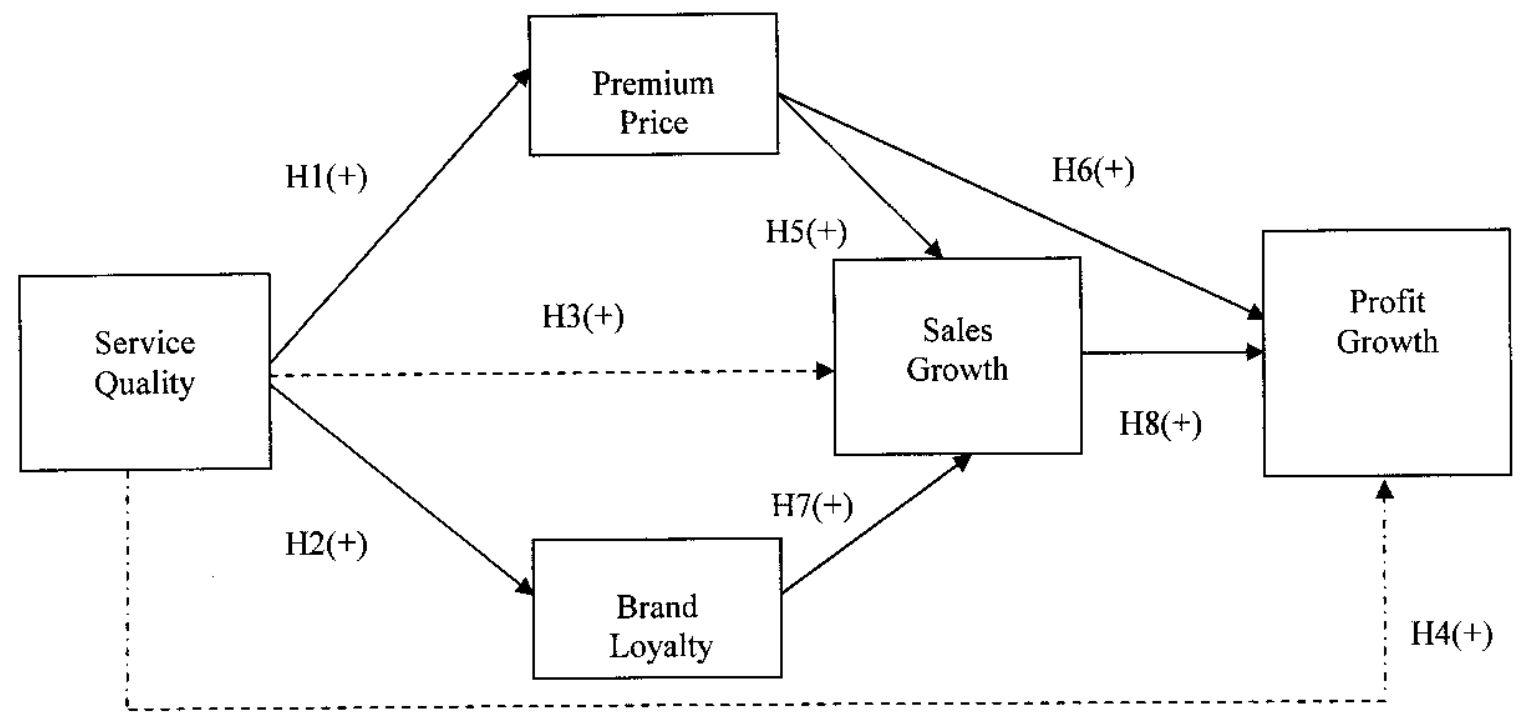

Figure 1. The research model. Solid lines: direct relationship; dotted lines: indirect relationship.

\section{Theoretical background}

\section{Service Quality}

Service quality is a complex and elusive concept. Several definitions from different perspectives have been introduced to understand its nature. Early definitions of quality suggest that quality can be defined objectively because it can be evaluated according to predetermined standards. However, this definition seemed to be more suitable to goods rather than services because goods are tangible and easy to standardize whereas services are intangible, subjectively evaluated, and difficult to standardize. To overcome this limitation, three different definitions of quality were offered to encapsulate the subjective nature of quality from the customer point of view: (1) quality is excellence; (2) quality is value; and (3) quality is meeting or exceeding expectations (Reeves \& Bednar, 1994).

The first definition of quality asserts that quality is excellence. However, this definition displays some inherent weaknesses, because the word "excellent" is highly subjective and difficult to measure. Hence, tracking the changes on perceived quality over a period of time is difficult. The second definition of quality implies that quality is synonymous with perceived value. But a growing number of studies suggest that perceived value and quality are different concepts (e.g., Bolton \& Drew, 1991; Zeithaml, 1988). Perceived value is seen as a ratio where customers make comparisons between the sacrifices they make in exchange for the benefits they get from using or obtaining a product. The sacrifice component usually refers to monetary costs (and/or time) and the perceived quality refers to product benefits. The third definition states that quality is meeting or exceeding customer expectations. Past studies, however, have shown that customer expectations are difficult to capture because they continuously change before, during, and after service consumption (Cronin \& Taylor, 1992). More recent studies suggest that service quality should be the same as perceived performance (Dabholkar, Shepherd, \& Thorpe, 2000; Ekinci, Dawes, \& Massey, 2008).

Another debate in the quality literature is whether service quality dimensions are generic or specific. This lack of consensus can largely be attributed to the fact that service quality research has been dominated by two schools of thought - the North American and the Nordic European-that have postulated different theories. The North American School initially introduced 10 service quality dimensions, best known as the SERVQUAL dimensions (Parasuraman, Zeithaml, \& 
Berry, 1985). Later, these dimensions were found to be highly correlated, and reduced to five dimensions: tangibles, assurance, reliability, empathy, and responsiveness (e.g., Carmen 1990; Parasuraman, Zeithaml, \& Berry, 1988). Researchers have investigated the number and nature of SERVQUAL dimensions in different service settings such as hotels, restaurants, and banks. Conclusions of the studies are mixed and, to date, there has been no clear agreement on these generic service quality dimensions (Buttle, 1996). Meanwhile, the Nordic European School (e.g., Grönroos, 1984; Lehtinen \& Lehtinen, 1991) introduced two generic service quality dimensions: (1) technical quality and (2) functional quality. They represent, respectively, what consumers obtain from a service firm as a result of using their services and how consumers obtain services.

\section{Brand Loyalty}

Most authors on this topic (e.g., Amine, 1998; Day, 1969; Dick \& Basu, 1994) argue that the loyalty concept is made up of two key components: behavioral and attitudinal. Behavioral loyalty is based on a consumer's repeated purchase of a specific brand chosen from the available alternatives (Jacoby \& Chestnut, 1978; Oliver, 1997). The latter incorporates consumer attitudes into brand loyalty. Attitudinal loyalty is not only cognitive but also emotional, and therefore can be observed when the consumer has a positive feeling towards a brand and is highly likely to recommend it (Agrawal, 1996).

\section{Premium Price}

Kotler, Bowen, and Makens' (2003) definition of price, "the amount of money charged for a good[s] or service" (p. 445), suggests that price is objective because it refers to the actual price of the product. Premium price is the extent to which the price paid by customers is considered higher than the average market price (Rao \& Bergen, 1992). In this study, premium price refers to a price where the budget hotel is able to charge a higher than the average budget hotel market price by offering better security, more convenient location, better quality of services, and in-house facilities, than similar budget hotels.

\section{Sales and Profit Growth}

Given the large number of academic studies in recent years in the area of profit and sales growth, it is surprising that very few researchers have, as yet, turned their attentions to the hospitality industry, which displays a number of characteristics of variety, variability, and volatility that would seem to give it rich potential (Zeglet, Ekinci, \& Lockwood, 2008). There are, however, a small number of authors who have approached this area directly and some others who have considered it as part of a broader study with a direct focus elsewhere (Garrigós-Simón, Marqués, \& Narangajavana, 2005; Phillips \& Louvieris, 2005). Generally speaking, the growth of hospitality firms is assessed through a combination of profitability and sales ratios. Thus, in this study we used the return on capital employed (ROCE) ratio and the sales percentage as complementary measures to assess the budget's hotel profitability.

Hypotheses Development

\section{Effects of Service Quality on Premium Price}

Customers are prepared to pay more for improved service quality where that quality provides customer satisfaction and perceived value (e.g., Falk, Hammerschmidt, \& Schepers, 2010; Neal, 1999). A considerable body of research suggests that consumers often use price as a heuristic to judge quality of service prior to purchase (e.g., Rao \& Monroe, 1989; Zeithaml, 1988). Interestingly, despite such a large number of qualityprice effect studies, there is little empirical research on the impact of service quality on price setting. The modeling work by Mendez and Narasimhan (2006) shows that an increase in quality commands an increase in price, regardless of the product's price elasticity of demand. They demonstrated that there is an explicit relationship between quality improvements and optimal prices, optimal prices being those that are not so high that they lead to reduced sales and profitability. Therefore, a firm offering superior service quality is able to charge higher prices than its competitors because higher quality indicates that the firm is offering more benefits and superior products than the competitors. This is especially relevant to ser- 
vices where the customer relies on a range of cues (price being a key one) to indicate quality; unlike goods, a service, being intangible, cannot be handled or examined before purchase. Accordingly, we posit that:

H1: Service quality will have a positive influence on premium price.

\section{Effects of Service Quality on Brand Loyalty}

Service quality is seen as an antecedent to customer satisfaction and customer retention (e.g., Duffy \& Ketchland, 1998; Taylor \& Baker, 1994). A large number of studies found that service quality had a positive impact on attitudinal and behavioral loyalty captured by word-of-mouth recommendation and intention to repurchase across different service sectors including hotels (Cronin, Brady, \& Hult, 2000; Dabholkar, Shepherd, \& Thorpe, 2000; Mittal \& Kamakura, 2001; Vijayadurai, 2008; Wilkins et al., 2010). A more recent study by Yee, Yeung, and Cheng (2010) focuses on the "labor intensive" high contact retail services in Hong Kong and concludes that service quality leads to customer loyalty and ultimately to firm profitability. Generally speaking, a positive evaluation of service quality forms favorable behavioral habits such as saying positive things about the brand and spending more with the company. Thus, we propose that:

$\mathrm{H} 2$ : Service quality will have a positive influence on brand loyalty.

\section{Effects of Service Quality on Sales and Profit Growth}

The positive linkage between quality and organizational performance has been recognized in the literature for several decades (e.g., Anderson, Fornell, \& Lehmann, 1994). As the voice of the customer assumes paramount importance in a service set-up, the service quality literature has recognized that the perceived quality of service is one of the keys to business growth (Bitner, 1990; Bolton \& Drew, 1991; Buttle, 1996; Cronin \& Taylor, 1992; Parasuraman, Zeithaml, \& Berry, 1988; Zeithaml, 1988). Benson, Saraph, and Schroeder (1991) argue that quality management practices enhance profitability through reducing waste and increasing pro- ductivity. The improved business performance occurs because of better market orientation and the ability to offer higher quality service (Slater \& Narver, 2000). In summary, where increased service quality reduces waste and creates efficiencies, profit goes up, where service quality increases the meeting of customers' needs, sales revenue increases due to preparedness to pay more (price premium) and to repeat purchase (loyalty). Thus we propose that:

H3: Service quality will have a positive influence on sales growth.

H4: Service quality will have a positive influence on profit growth.

\section{Effects of Premium Price on Sales and Profit Growth}

Price is one of the essential determinants of sales growth and profit growth (Kotler et al., 2003). It is self-evident that if price is increased and the demand remains stable (i.e., no additional costs incurred for a product), profit will increase. However, an increased price can deter demand; this demand may be reduced to such an extent that overall total sales revenue is decreased. Decision makers must determine the optimum price (i.e., one that raises revenue and maintains or grows sales). If the brand is a market leader in its sector, it can increase its price (to a certain extent) and not see profits reduced, the same applies to the purveyors of "risky" services (e.g., Allred, Valentin, \& Chakraborty, 2010) where premium prices can signal a higher quality and so reduce perceived risk leading to increased sales revenue and profit. Higher revenue growth is likely to create greater profit margins. Potentially the higher the price, the higher the sales revenue growth and related profit growth. Thus, we propose that;

H5: Premium price will have a positive influence on sales growth.

H6: Premium price will have a positive influence on profit growth.

\section{Effects of Brand Loyalty on Sales Growth}

Repeat purchase behavior and customer retention are important guiding principles for a firm as they help to increase sales revenue and reduce 
marketing costs. Benefits of customer retention are recognized through its impact on a number of facets of business performance, including increased sales and profit growth (Oliver, 1999; Reicheld \& Sasser, 1990). Loyal customers also attract new customers through spreading positive word-ofmouth (Zeithaml et al., 1996). Past studies support the positive relationship between brand loyalty and sales growth, leading to higher market share (Helgesen, 2006; Kumar \& Shah, 2004; Rust \& Zahorik, 1993). Better customer retention tactics result in increased market share and sales revenue (Rust et al., 1995). Thus we propose that;

H7: Brand loyalty will have a positive influence on sales growth.

\section{Effects of Sales Growth on Profit Growth}

Increased sales growth will translate into higher profits, except where considerable costs have been incurred to drive sales and the negative impact on profit is expected to be short term (Adam, 1994; Harrington \& Akehurst, 1996; Sterman et al., 1997). In most cases, sales growth provides financial benefits for companies due to improved economies of scale, better bargaining power and cash flow management (Aaker, 1995). Sales growth also improves market share and therefore increases profitability (Buzzell \& Gale, 1987; Schoeffler, Buzzel, \& Heany, 1974; Szymanski, Bharadwaj, \& Varadarajan, 1993). Thus we propose that:

H8: Sales growth will have a positive influence on profit growth.

\section{Method}

\section{The Sample and the Data}

The data were obtained in 2006 from a leading hotel company that operates 183 nation-wide branded budget hotels across the UK. Hence, the unit of analysis was a budget hotel. A budget hotel is defined as "a hotel operation offering nightly room rental with few added services beyond a continental breakfast, a meeting room, and perhaps a limited exercise facility" (Hinton, 2008, p. 47).

Within the 183 budget hotels in the chain, prices differ at each location depending on the convenience of the location and attractiveness of the hotel facilities and services offered at that ho- tel. Prices are set by the Head Office within a range from low to premium price. The budget hotel business model operates on a low-cost/lowprice basis. All prices are set with a view to ensuring the customer perceives the offer to be a good value for money. Like other services in the value sector, budget hotels serve a price-sensitive market, where price elasticity is high. In accordance with their business model they, more than other hotel sectors, rely on very high occupancy levels as a significant percentage of their costs are indirect (overheads) with low direct costs (Hinton, 2008). It is this business model and price sensitivity that leads to a need for a precise balance of service costs and pricing structures. It is in this context that the data were gathered to test the proposed "service quality-brand loyalty/premium price-profit growth" model.

\section{Measures}

The most prominent service quality measurement scale-SERVQUAL_-is designed to measure perceptions of service quality using multiple attributes on five dimensions: tangibility, reliability, responsiveness, assurance, and empathy (Parasuraman et al., 1988). Although SERVQUAL has been popular, it is vulnerable to criticisms from a theoretical (the validity of the SERVQUAL dimensions) and operational perspective (the difficulty of administering the expectation and performance part to the same individual, before and after service evaluation) (Buttle, 1996). Thus, the reliability and validity of the SERVQUAL scale have been questioned. The recent literature on service quality suggests that it should be measured through industry-specific scales that capture perceived performance of the service provider (Ekinci et al., 2008).

Another widely used method for monitoring service quality in the hospitality industry is mystery shopping (Beck \& Miao, 2003). Finn's (2001) study results confirmed that "mystery shoppers can provide a viable alternative to customer survey methods for benchmarking retail performance" ( $p$. 318). Mystery shopping is a form of participant observation, using people to act as customers or potential customers to measure performance against predetermined quality standards. It is frequently 
used in the service industry because it is a very pragmatic way to monitor employee and system performance. Exploratory research undertaken by Wilson (2008) on the role of mystery shopping for measuring and managing service quality concluded that it is a reliable technique. Finn and Kayande (1999) used the Generalizability Theory to investigate the efficiency of mystery shopping data for the assessment of store service quality. Their study found that ratings data collected by mystery shoppers are of higher quality than data obtained from the SERVQUAL-based customer surveys, even when both methods use a common service quality assessment for scaling stores. Their study concluded that

\begin{abstract}
When evaluating the same subjective constructs, an individual mystery shopper provides higher quality data than does an individual customer. As a result, a mystery shopping study can provide desirable high reliability information at a far lower cost than a traditional customer survey, when comparing outlets on service quality. (p. 212)
\end{abstract}

In our study, service quality was measured by the hotel general managers via an auditing instrument. The general managers - in the guise of mystery shoppers - visited one of the budget hotels in the chain in 2005. Using a 100-point scale developed by the company, they rated the various attributes of service quality (e.g., cleanliness of the room, overall behavior and attitude of service personnel, reliability of service, attractiveness of décor, variety of hotel facilities, quality of food, etc.). An aggregated score of service quality for each hotel was reported to the head office. Higher service quality represents a higher score on this scale.

The brand loyalty data were collected from the hotel customers at the check-out point using a personally administered customer survey questionnaire. Customer perception of brand loyalty was assessed using a question: "How likely is it that you will recommend this hotel?," on a scale of 0 to 100 where a higher score indicated a higher likelihood of recommendation. This question is seen as the most vital, and in many ways the most simple, one to be answered when measuring attitudinal loyalty (Reicheld, 2003). The brand loyalty score of each hotel was determined by averaging measures taken from all these customer surveys in 2005.

The price of the room was determined by Head Office according to market conditions, taking into account a competition, location of the hotel, and condition of the hotel facilities. The average room price for each hotel was obtained in 2005 from the Head Office.

A number of profitability ratios are recommended to assess a hotel's profitability such as revenue per available room (RevPAR), total gross operating profit (GOP), and return on capital employed (ROCE) (Zeglat et al., 2008). RevPAR indicates the performance of a hotel in terms of room inventory management and offers some general market trends; however, it provides no cost indication of a hotel property and therefore how much money it is actually-or could be-making. GOP is equal to total revenue less the total departmental and operating expenses, and provides an indication of the hotel operation's efficiency. However, it does not allow an accurate evaluation of the net revenue and the room revenue, particularly in the budget hotels, which make up to $90 \%$ of their revenues from rooms (Younes \& Kett, 2003).

In this research, ROCE is used to confirm the value the business gains from its assets and liabilities. Profit growth was determined by comparing the hotels' ROCE ratio between 2005 and 2006. As there is no single indicator of profitability, in addition to the ROCE ratio, we used hotel revenue as a proxy to the budget hotels' profit growth. The revenue growth ratio was calculated by comparing each hotel's 2006 sales against their 2005 sales.

The service quality, brand loyalty, price, sales growth, and profit growth data were collected by Head Office for strategic planning and monitoring each hotel's performance and used for this research study.

\section{Findings}

\section{Descriptive Statistics}

Table 1 presents descriptive statistics and correlation matrix. As can be seen from the table, the average quality of service rating is deemed to be $84 \%$. Brand loyalty was below the average $(42 \%)$. The mean average hotel price was $£ 55$ with a standard deviation of 5.64. The sales and profit in- 
Table 1

Correlation Matrix

\begin{tabular}{lrrlllll}
\hline Variable & Mean & SD & \multicolumn{1}{c}{1} & \multicolumn{1}{c}{2} & \multicolumn{1}{c}{3} & 4 & 5 \\
\hline 1. Service quality & 0.84 & 0.04 & 1 & & & & \\
2. Brand Loyalty & 0.42 & 0.07 & $0.24^{* *}$ & 1 & & & \\
3. Premium price & 55.00 & 5.64 & $0.24^{* *}$ & 0.10 & 1 & & \\
4. Sales growth & 0.06 & 0.04 & 0.09 & $0.17^{*}$ & $0.17^{*}$ & 1 & \\
5. Profit growth & 0.14 & 0.17 & 0.02 & $0.16^{*}$ & $-0.15^{*}$ & $0.52^{* *}$ & 1 \\
\hline
\end{tabular}

*Pearson correlation coefficients significant at the 0.05 level (two-tailed).

$* *$ Pearson correlation coefficients significant at the 0.01 level (two-tailed).

creased on average $6 \%$ and $14 \%$, respectively, from 2005 to 2006. The findings in Table 1 also indicate that service quality was positively correlated with brand loyalty $(r=0.24, p<0.05)$ and premium price $(r=0.24, p<0.05)$ as expected. Sales growth and profit growth were moderately correlated $(r=0.52, p<0.05)$. No statistically significant relationship was found between service quality and the two business growth indicators: sales and profit growth.

\section{Test of Hypotheses}

Causal path modeling software-LISREL 8.72was used to estimate the structural model and test the research hypotheses (Bearden, Netemeyer, \& Teel, 1989; Chin \& Todd, 1995). The overall fit of the measurement model was determined initially by examining the chi-square statistics. A significant chi-square value indicates an inadequate fit, but one should be cautious in interpreting the results because chi-square statistics are dependent on sample size (Bollen, 1989; Jöreskog \& Sörbom, 1989). Therefore, a wide range of fit indices has been introduced to overcome the deficiency of sample size (Hu \& Bentler, 1998). These are Goodness of Fit Index (GFI), Normed Fit Index (NFI), Comparative Fit Index (CFI), and Root Mean Square Error of Approximation (RMSEA) and are relatively unaffected by sample size. Table 2 displays the test of the model and the summary statistics.

The model fit indices were in line with the acceptable thresholds. The $\chi^{2}(4)=5.54$, was not significant as expected due to sample size. The other fit indices exceeded the recommended thresholds: $\mathrm{GFI}=0.99 ; \mathrm{AGFI}=94, \mathrm{NNFI}=0.90 ; \mathrm{CFI}=0.97$.
The standardized RMR (0.04) and RMSEA (0.06) were below the accepted cut-off value of 0.08 . Thus, the model fit indices were predominantly good. The structural model explained $34 \%$ of the variance in profit growth.

In short, we found support for six of the eight hypotheses. The hypotheses suggesting the positive influence of service quality on brand loyalty $(\mathrm{H} 1, \mathrm{SPC}=0.16, p<0.05)$ and premium price $(\mathrm{H} 2, \mathrm{SPC}=0.32, p<0.01)$ were supported. We rejected $\mathrm{H} 3$ and $\mathrm{H} 4$, which posited that service quality would have a positive influence on sales growth $(\mathrm{SPC}=0.07, p>0.05)$ and profit growth $(\mathrm{SPC}=$ $-0.10, p>0.05)$. These findings indicate that the effect of service quality on profit growth is indirect. We did also find support for $\mathrm{H} 5$ (SPC $=0.15$, $p<0.05$ ), which suggests that brand loyalty is an antecedent to sales growth. Similarly, we found support for H6 (SPC $=0.15, p<0.05$ ), which posited that premium price had a positive impact on sales growth. Although $\mathrm{H} 7$ was supported (SPC $=$ $-0.18, p<0.05)$, the impact of premium price on profit growth was negative rather than positive. We believe that this is due to the complexity of the price-capacity management relationship and the price elasticity of demand in the budget hotel sector. The price elasticity argument is that a unit of increase in price causes a relatively greater reduction in occupancy and therefore profit growth is negatively influenced by sharp price increases. Finally, H8 was strongly supported, which posited that sales growth had a positive influence on profit growth $(\mathrm{SPC}=0.55, p<0.05)$.

\section{Conclusions}

In summary, our study suggests that both premium price and brand loyalty act as mediators be- 
tween service quality and sales growth. Furthermore, premium price and sales growth have a direct relationship with profit growth. The key implication of this study is that it has contributed to the ongoing debate about whether service quality has a direct or indirect influence on profitability in the service industry as suggested by Zeithaml (2000). We also addressed the need for better understanding of the theoretical relationship between service quality and profitability as well as the impact of service quality on profitability as raised by Babakus et al. (2004). This claim is based on the grounds that we found strong empirical support for six of the eight hypotheses in our model. Overall, our study findings indicated that the impact of service quality on profit growth was indirect in the budget hotel sector. The influence of service quality on sales growth was through brand loyalty. Sales growth had a positive impact on profit growth, whereas premium price had a negative impact. Service quality had a positive influence on premium price and brand loyalty and therefore these findings confirmed Mendez and Narashimhan's (2006) and Dabholkar et al.'s (2000) results.

The hypotheses that posited that service quality would have a direct effect on sales growth and profit growth were rejected in our study. We argue that this could be related to the price and capacity management issues in the hotel industry. In subsequent research these variables need to be incorporated in a framework that will predict the direct and indirect relationships between service quality and profit growth and so enable a greater understanding of these relationships within the price sensitive budget/value sector.

The key implication for hotel managers is that efforts concentrated on improving service quality could eventually have a positive effect on bottom line profits (i.e., mediated-and managed - through brand loyalty and growth in sales revenue). There is a minimum service level that is expected and/or required by the customer and if additional services (which will add to the hotel's costs) are offered they cut into the hotel's profitability. Improving service quality offers opportunities to increase profits by charging a premium price and engender brand loyalty (and therefore repeat business). However, price increases invites newcomers into the marketplace and so further increasing competition and this could lead to reduced occupancy levels. Reduced occupancy hits budget hotels particularly hard as their business model operates with comparatively high indirect costs (overheads) compared to the direct costs (costs per customer). In other words, the marginal costs of serving an additional customer are low-as a percentage of all costs - compared to more up-market hotels that offer more services related to individual guests' needs. Although budget hotels require a relatively high occupancy level in order to break even, after they have reached that point, a very high percentage of the revenue from any additional customers adds directly to bottom-line profits. In that circumstance high occupancy is very profitable.

Table 2

Test of the Research Model

\begin{tabular}{|c|c|c|c|}
\hline Hypothesis No. & Relationship & $\begin{array}{c}\text { Standardized } \\
\text { Path Coefficient (SPC) }\end{array}$ & $t$-Value \\
\hline H1 & Service quality $\rightarrow$ Brand loyalty & 0.16 & $2.13 *$ \\
\hline $\mathrm{H} 2$ & Service quality $\rightarrow$ Premium price & 0.32 & $4.62 * *$ \\
\hline $\mathrm{H} 3$ & Service quality $\rightarrow$ Sales growth & 0.07 & 0.93 \\
\hline $\mathrm{H} 4$ & Service quality $\rightarrow$ Profit growth & -0.10 & -1.52 \\
\hline H5 & Brand loyalty $\rightarrow$ Sales growth & 0.15 & $2.08 *$ \\
\hline H6 & Premium price $\rightarrow$ Sales growth & 0.15 & $2.10^{*}$ \\
\hline $\mathrm{H} 7$ & Premium price $\rightarrow$ Profit growth & -0.18 & $-2.77 *$ \\
\hline H8 & Sales growth $\rightarrow$ Profit growth & 0.55 & $8.97 * *$ \\
\hline
\end{tabular}

Model fit statistics: chi-square $=5.54, d f=4$, RMSEA $=0.06, \mathrm{RMR}=0.04, \mathrm{GFI}=0.99$, $\mathrm{NNFI}=0.90, \mathrm{CFI}=0.97$, percent of variance explained in profit growth $\left(R^{2}\right)=0.34$.

$* p<0.05$.

$* * p<0.01$. 
So, in summary, given the business model, the price elasticity, and the increasing levels of competition in this sector, the key implications for managers from our research is that profits can be increased as a result of increased sales revenue. This increased revenue is a result of charging premium prices, increasing value proposition, and growing brand loyalty. In turn these increased prices and loyalty are enabled by increased service quality. The findings of this study confirmed the results of past studies conducted by Allred et al. (2010), Mittal and Kamakura (2001), and Zeithaml (1988). However, a balance needs to be struck between (1) maintaining occupancy levels to at least the break-even point and (2) improving service quality in such a way that premium prices can be charged at a level where value for money is maintained and brand loyalty increased. Brand loyalty will contribute towards maintaining occupancy levels and the balance between the higher costs of improved service quality must be adjusted in relationship to the willingness of the customer to pay a premium price.

Maintaining brand loyalty over time is therefore important; this is linked to customer expectations and their understanding of the competition's offer. A concern here is that although service quality will allow a service organization to achieve a premium price, this may actually be counterproductive in the budget hotel market where price sensitivity is high. Hence, a larger increase in price may have an adverse effect on demand and future profitability. There is further work that needs to be done to investigate whether this rather counterintuitive phenomenon occurs at other hotel sectors such as midmarket and luxury segment.

Although our study makes contributions to the understanding of the relationship between service quality and profit growth, it has limitations. First, the study is restricted to the budget hotel sector and so future researchers need to extend our research to other hotel firms. In addition, there are opportunities to extend the model developed here to other "budget" sectors such as those in the airline or retail industries. Second, the data set is only UK based and therefore our findings cannot be generalized to other service sectors and other service firms in different countries.

\section{References}

Aaker, D. (1995). Strategic marketing management (4th ed.). New York: John Wiley and Sons.

Adam, E. (1994). Alternative quality improvement practices and organization performance. Journal of Operations Management, 12(1), 27-44.

Agrawal, D. (1996). Effect of brand loyalty on advertising and trade promotions: A game theoretic analysis with empirical evidence. Marketing Science, 15(1), 86-108.

Allred, A., Valentin, E. K., \& Chakraborty, G. (2010) Pricing risky services: Preference and quality considerations. Journal of Product and Brand Management, 19(1), 54-60.

Amine, A. (1998). Consumers' true brand loyalty: The central role of commitment. Journal of Strategic Marketing, 6(4), 305-319.

Anderson, E., Fornell, C., \& Lehmann, D. (1994). Customer satisfaction, market share, and profitability: Findings from Sweden. Journal of Marketing, 58(3), 53-66.

Babakus, E., Bienstock, C., \& Scotter, J. (2004). Linking perceived quality and customer satisfaction to store traffic and revenue growth. Decision Science, 35(4), 713737.

Bearden, W. O., Netemeyer, R. G., \& Teel, J. E. (1989). Measurement of consumer susceptibility to interpersonal influence. Journal of Consumer Research, 19, 473-481.

Beck, J., \& Miao, L. (2003). Mystery shopping in lodging properties as a measurement of service quality. Journal of Quality Assurance in Hospitality and Tourism, 4(1/ 2), 1-21.

Benson, P. G., Saraph, J. V., \& Schroeder, R. G. (1991). The effects of organizational context on quality management: An empirical investigation. Management Science, 37(9), 1107-1124.

Bitner, M. J. (1990). Evaluating service encounters: The effects of physical surroundings on consumers and employees. Journal of Marketing, 54(2), 69-81.

Buttle, F. (1996). SERVQUAL: Review, critique, research agenda. European Journal of Marketing, 30(1), 8-32.

Buzzell, R., \& Gale, B. (1987). The PIMS principles: Linking strategy to performance. New York: Free Press.

Bolton, R. N., \& Drew, J. H. (1991). A multistage model of customers' assessment of service and value. Journal of Consumer Research, 17(4), 375-384.

Bollen, K. A. (1989). Structural equations with latent variables. New York: John Wiley and Sons.

Carmen, J. M. (1990). Consumer perceptions of service quality: An assessment of the SERVQUAL dimensions. Journal of Retailing, 66(1), 33-55.

Chin, W., \& Todd, P. A. (1995). On the use, usefulness, and ease of use of structural equation modeling in MIS research: A note of caution. MIS Quarterly, 19(2), 237246.

Cronin, J., Brady, M., \& Hult, G. (2000). Assessing the effects of quality, value, and customer satisfaction on behavioral intentions in service environment. Journal of Retailing, 67(2), 193-218. 
Cronin, J. J., \& Taylor, S. A. (1992) Measuring service quality: A reexamination and extension. Journal of Marketing, 56(3), 55-65.

Dabholkar, P. A., Shepherd, D. A., \& Thorpe, D. I. (2000). A comprehensive framework for service quality: An investigation of critical conceptual and measurement issues through a longitudinal study. Journal of Retailing, $76(2), 139-173$.

Day, G. S. (1969). A two dimensional concept of brand loyalty. Journal of Advertising Research, 9(3), 29-35.

Dick, A. S., \& Basu, K. (1994). Customer loyalty: Toward an integrated conceptual framework. Journal of the Academy of Marketing Science, 22(2), 99-113.

Duncan, E., \& Elliott, G. (2002). Customer service quality and financial performance among Australian retail financial institutions. Journal of Financial Service Marketing, 7(1), 25-41.

Duffy, J. A. M., \& Ketchand, A. A. (1998). Examining the role of service quality in overall service satisfaction. Journal of Managerial Issues, 10(3), 240-266.

Ekinci, Y., Dawes, P., \& Massey, G. (2008). A model of consumer satisfaction for services. European Journal of Marketing, 42(1/2), 35-68.

Falk, T., Hammerschmidt, M., \& Schepers, J. (2010). The service quality satisfaction link revisited: Exploring asymmetries and dynamics. Journal of the Academy of Marketing Science, 38(3), 288-302

Finn, A. (2001). Mystery shopping benchmarking of durable-goods chains and stores. Journal of Service Research, 3(4), 310-320.

Finn, A., \& Kayende, U. (1999). Unmasking a phantom: A psychometric assessment of mystery shopping. Journal of Retailing, 75(2), 195-217.

Garrigós-Simón F. J., Marqués D. P., \& Narangajavana Y. (2005). Competitive strategies and performance in Spanish hospitality firms. International Journal of Contemporary Hospitality Management, 17(1), 22-38.

Garuana, A., \& Pit, L. (1997). INTQUAL-An internal measure of service and the link between service quality and business performance. European Journal of Marketing, 3(8), 604-616.

Gold, M. (2008). Quantification of serviced accommodation supply in the United Kingdom and consideration of related issues. Retrieved January 10, 2010, from www. melvingoldconsulting.com

Gronroos, C. (1984). A service quality model and its marketing implications. European Journal of Marketing, 18(4), 36-44.

Hardie, N. (1998). The effects of quality on business performance. Quality Management Journal, 5(3), 65-83.

Harrington, D., \& Akehurst, G. (1996). Service quality and business performance in the UK hotel industry. International Journal of Hospitality Management, 15(3), 283286.

Hasan, M., \& Kerr, R. (2003). The relationship between total quality management practices and organizational performance in service organizations. The TQM Magazine, 15(4), 286-291.
Helgesen, Ø. (2006). Are loyal customers profitable? Customer satisfaction, customer (action) loyalty, customer profitability at the individual level. Journal of Marketing Management, 22(3/4), 245-266.

Hendricks, K. B., \& Singhal, V. R. (1997). Does implementing an effective TQM program actually improve operating performance? Empirical evidence from firms that have won quality awards. Management Science, 43(9), 1258-1274.

Hinton, B. (2008). Valuing limited-service hotel: A pragmatic framework from a broker's Perspective. The Appraisal Journal, 76(1), 47-53.

Hu, L., \& Bentler, P. M. (1998). Fit indices in covariance structure modeling: Sensitivity to under parameterized model misspecification. Psychological Methods, 3(4), 424-453.

Jacoby, J., \& Chestnut, R. W. (1978). Brand loyalty measurement and management. New York: John Wiley and Sons.

Johnson, B. (2003, September 25). Frills seeking antics of budget hotels. Marketing Week, 19-20.

Jöreskog, K. G., \& Sörbom, D. (1989). LISREL 7: A guide to the program and applications. Chicago: SPSS.

Kimes, S. E. (2001). How product quality drives profitability. Cornell Hotel and Restaurant Administration Quarterly, 42(3), 25-28.

Kotler, P., Bowen, J., \& Makens, J. (2003). Marketing for hospitality and tourism (3rd ed.). New York: Prentice Hall.

Kuhn, K. (2007). Budget hotels set to double market share in 20 years. Caterer and Hotelkeeper, 197(4506), 7.

Kumar, V., \& Shah, D. (2004). Building and sustaining profitable customer loyalty for the 21 st century. Journal of Retailing, 80(4), 317-330.

Lehtinen, U., \& Lehtinen, J. R. (1991). Two approaches to service quality dimensions. The Service Industries Journal, 11(3), 287-303.

Mendez, D., \& Narasimhan, R. (2006). Dynamic interaction among price, quality, durability, and the sales rate in a steady state environment: A theoretical analysis. Mathematical and Computer Modeling, 44(1/2), 49-64.

Mittal, V., \& Kamakura, W. (2001). Satisfaction, repurchase intent, and repurchase behavior: Investigating the moderating effect of customer characteristics. Journal of Marketing Research, 38(1), 131-142.

Neal, W. D. (1999). Satisfaction is nice, but value drives loyalty. Marketing Research, 11(1), 21-24.

Oliver, R. L. (1997). Satisfaction: A behavioral perspective on the consumer. New York: McGraw-Hill.

Oliver, R. L. (1999). Whence consumer loyalty? The Journal of Marketing, 63, 33-44.

Parasuraman, A., Zeithaml, V., \& Berry, L. (1985). A conceptual model of service quality and its implications for future research. Journal of Marketing, 49(4), 41-50.

Parasuraman, A., Zeithaml, V., \& Berry, L. (1988). SERVQUAL: Multiple-item scale for measuring consumer perceptions of service quality. Journal of Retailing, 64(1), 12-40. 
Philips, L. W., Change, D. R., \& Buzzell, R. D. (1983). Product quality, cost position, and business performance: A test of some key hypotheses. Journal of Marketing, 47(2), 26-43.

Phillips, P., \& Louvieris, P. (2005). Performance measurement systems in tourism, hospitality, and leisure small medium-sized enterprises: A balanced scorecard perspective. Journal of Travel Research, 44(2), 201-211.

Raju, P. S., \& Lonial, S. C. (2002). The impact of service quality and marketing on financial performance in the hospital industry: An empirical examination. Retailing and Consumer Services, 9(6), 335-348.

Rao, A. R., \& Bergen, M. E. (1992). Price premium variations as a consequence of buyers' lack of information. Journal of Consumer Research, 19(3), 412-423.

Rao, A. R., \& Monroe, K. (1989). The effect of price, brand name, and store name on buyers' perceptions of product quality: An integrative review. Journal of Marketing Research, 26(3), 351-357.

Reeves, C. A., \& Bednar, D. A. (1994). Defining quality: Alternatives and implications. Academy of Management Review, 19(3), 419-445.

Reicheld, F. F. (2003). The one number you need to grow. Harvard Business Review, 81, 2-10.

Reichheld, F. F., \& Sasser, Jr., W. E. (1990). Zero defections: Quality comes to service. Harvard Business Review, 68(5), 105-111.

Rust, R., Lemon, K., \& Narayands, D. (2004). Customer equity management. New York: Pearson Prentice Hall.

Rust, R., Moorman, M., \& Dickson, P. (2002). Getting return on quality: Revenue expansion, cost reduction, or both? Journal of Marketing, 66(4), 7-24.

Rust, R., \& Zahorik, A. (1993). Customer satisfaction, customer retention, and market share. Journal of Retailing, 69(2), 193-215.

Rust, R., Zahorik, A., \& Keiningham, T. (1995). Return on quality (ROQ): Making service quality financially accountable. Journal of Marketing, 58(2), 58-70.

Schoeffler, S., Buzzel, R., \& Heany, D. (1974). Impact of strategic planning on profit performance. Harvard Business Review, 52(2), 137-145.

Slater, S. F., \& Narver, J. C. (2000). The positive effect of market orientation on business profitability a balanced replication. Journal of Business Research, 48(1), 69-73.

Sterman, J., Repenning, N., \& Kofman, F. (1997). Unanticipated side effects of successful quality programs: Exploring a paradox of organizational improvement. Management Science, 43(4), 503-521.
Szymanski, D., Bharadwaj, S., \& Varadarajan, P. (1993). An analysis of the market share-profitability relationship. Journal of Marketing, 57(3), 1-18.

Taylor, S. A., \& Baker, T. L. (1994). An assessment of the relationship between service quality and customer satisfaction in the formation of consumers' purchase intentions. Journal of Retailing, 70(2), 163-178.

Vijayadurai J. (2008). Service quality, customer satisfaction, and behavioral intention in hotel industry. Journal of Marketing and Communication, 3(3), 14-26

Wilkins, H., Merrilees, B., \& Herington, C. (2010). The determinants of loyalty in hotels. Journal of Hospitality Marketing and Management, 19(1), 1-21.

Wilson, A. M. (1998). The role of mystery shopping in the measurement of service performance. Managing Service Quality, 8(6), 414-420.

Yee, R. W. Y., Yeung, A. C. L., \& Cheng, T. C. E. (2010). An empirical study of employee loyalty, service quality, and firm performance in the service industry. International Journal of Production Economics, 124(1), 109120.

Youness, E., \& Kett, R. (2003). GOPPAR a derivative of RevPAR. Retrieved November 24, 2010, from http:// www.hotelmarketing.com/index.php/content/article/gop par_a derivative_of_revpar/

Zeglat, D., Ekinci, Y., \& Lockwood, A. (2008). Service quality and business performance in the hospitality industry. In H. Oh (Ed.), Handbook of hospitality and tourism marketing (pp. 209-236). London: Elsevier.

Zeithaml, V. (1988). Consumer perceptions of price, quality, and value: A means-end model and synthesis evidence. Journal of Marketing, 52(3), 2-22.

Zeithaml, V. A. (2000). Service quality, profitability, and the economic worth of customers: What we know and what we need to learn. Journal of the Academy of Marketing Science, 28(1), 67-85.

Zeithaml, V. Berry, L., \& Parasuraman, A. (1988). Communication and control processes in the delivery of service quality. Journal of Marketing, 52(2), 35-48.

Zeithaml, V. A., Berry, L. L, \& Parasuraman, A. (1996). The behavioral consequences of service quality. Journal of Marketing, 60(2), 31-46.

Zhang, Z. (2000). Developing a model of quality management methods and evaluating their effects on business performance. Total Quality Management, 11(1), 129137. 